- Değini . Viewus -

\title{
Türlerin Ayrımı: “Blade Runner 2049”a Ontolojik Bakış Açısı ile Tanrı ve İnsan Felsefesi
}

\author{
Buse Uzun
}

Dünya tarihi üzerinde insanın dünya ile tarihi ilişkisi hakkında birçok bilgi bulunmakta ve bunların en çok yaygın olarak bilineni ise kutsal kitaplarda yer almaktadır. İnsanın dünya tarihinde başlangıcı olarak kabul edilen Âdem ile Havva'nın hikayesidir. Bu hikâye de insanın atası olarak bilinen Âdem ile Havva'nın anlatılan öyküsü şöyledir: Tanrı'nın yarattığı yabanıl hayvanların en kurnazı yılandı. Yılan kadına (Havva), "Tanrı gerçekten bahçedeki ă̆açların hiçbirinin meyvesini yemeyin dedi mi?" diye sordu. Kadın, "Bahçedeki ă̆açlarm meyvelerinden yiyebiliriz" diye yanitladı, "ama Tanr, bahçedeki ağacm meyvesini yemeyin, ona dokunmayın; yoksa ölürsünüz" dedi. Yılan "Kesinlikle ölmezsiniz" dedi, "Çünkü Tanrı biliyor ki, o ağacın meyvesini yediğinizde gözleriniz açılacak, iyiyle kötüyü bilerek Tanrı gibi olacaksınız." Kadın ağacın güzel, meyvesinin yemek için uygun ve bilgelik kazanmak için çekici olduğunu gördü. Meyveyi koparıp yedi. Yanındaki kocasına da (Âdem) verdi, o da yedi. O zaman ikisinin de gözleri açıldı ve ikisi de çıplaklıklarını gördüler. İncir yapraklarını birbirine dikerek önlerini örttüler. (Yaratılış 3:1-7)

Kulaktan kulağa geçmiş kutsal dinlere ve hatta mitlere de konu olmuş bu hikâye de Şeytan Havva'ya, Havva'da Adem'e yasak elmayı yedirmiştir. Bu sebeple de Tanrı insanı cennetteki nimetlerinden yoksun bırakıp, ölümlü olmakla cezalandırarak cennetinden kovmuştur. Bu hikâye birçok filme, resme, öykülere de konu olmuştur. Buradaki elma ağaçları yeniden doğuşun ve üremenin sembolüdür. Bu ağaç iyi ve kötüyü bilme ölçütü sunan bilgelik ağacıdır. Bu ağaç gerçekten de elma ağacı mıdır, yoksa anlatılanlar bir sembolik olarak mı adlandırılmıştır bilinmez ama elmayı yiyen Havva ve Âdem cennetten kovulmuş, Dünya'ya sürgüne gönderilerek cezalandırılmıştır. Bu sürgünün anlamı insan dünyadaki varlığını sonlandırıncaya kadar yani cezasını çekene kadar kalacaktır iş̧te o zaman sürgünü bitecek ve geri dönecektir. Bu geri dönüşün ruhani bir yolculuk olduğu da tefsir edilmektedir.

İnsanlık ve dünya tarihi hakkında anlatılanlardan kaynak alarak daha ileriye yaratılıştan önceye gidersek kötülüğ ün ve insanın düşmanı haline gelmiş Şeytan (Düşmüş Melek) ile karşılaşırız. "Şeytan, Dante'ye şöyle söyledi: Tanrıyı gerçekten tanısaydın sende ihanet ederdin..." (Comencia La Comedia, 1472) Dante İlahi Komedyasın' da Lucifer'1 şöyle anlatır. “Tanr, Adem'i yarattıktan sonra meleklerine ve Lucifer'a "Âdem önünde eğilin" demiştir. Bunun üzerine Lucifer isyan etmiş ve Tanrı kendisine karşı çıktığ iç̧in Lucifer'ı kovmuştur. Fransız ressam Alexander Cabanel 1898 yılında yaptığ ‘ 'Düşmü̧̈ Melek' tablosunda Şeytan tasvirini Tevrat metinlerinde geçen haline dayanarak resmediyor. "Sen güzeller ve bilgeler içinde en 
mükemmeldin. Tanri'nın bahçesinde Eden'de idin. Elbiselerin işlemeli taşlarla ve altınla süslüydü. Bunlar sana yaratıldığında verildi. Gücünden kudretinden dolayı seni bekçim yaptım. Tanrının kutsal dağına ve ateş tarlalarına girebiliyordun. Yaptığın hiçbir şeyden sorumlu tutulmuyordun. Sonunda için kötülükle doldu. Şiddeti yarattın ve günahkâr oldun. Bu yüzden seni Tanrı dağından men ettim. Seni ateş tarlalarının bekçiliğinden men ettim. Güzelliğinden dolayı için kibirle doldu. Bilgeliğini ise kibrin ve ünün için kullandın. İçindeki ateşle birlikte seni dünyaya hapsettim. Senin peşinden gelenlerle birlikte sonsuz ateşler içinde yanacak, küllere dönüşeceksin. Bu senin feci sonundur." (Tevrat) Cabanel yapmış olduğu tabloda Şeytan ile empati kurma şansını sunar ve hatta Şeytan'ı öyle güzel resmeder ki tarihin en ikonik resimlerinden birini oluşturur. İçimizdeki Şeytan'a kimi zaman ihanet ettiğimiz ya da ihanete uğradığımız zamanlara atıfta bulunur. Dünya tarihinde insanın ve kötülüğün sembolü olan Şeytan'ın anlatılan hikayesi böyle başlar.

\section{Sinema ve Felsefe İlişkisi}

İnsanların ilk kez tuvale fırça sürmesinden binlerce yıl önce atalarımız mağara duvarlarını basit figürlerle karmaşık av sahneleriyle ve daha pek çok resimle süslediler. (Sanat 101, 245) Mağara resimlerinin büyük bir çoğunluğunun odağında eski insanların gündelik hayatta karşılaşıp avladığı büyükbaş hayvanlar vardır. Atalarımızın böylesine karmaşık sanat eserlerini niçin yapıp nesilden nesile aktardığını hiçbir zaman öğrenemeyeceğiz ama bu konudaki teoriler yabana atılmayacak kadar çoktur. İnsan temsilini yasaklayan tabulardan hareket eden bazı antropologlar söz konusu resimlerin dini anlamlar içerebileceği görüşündedirler. İster sihirsel, ister dinsel, ister kültürel amaçlı olsun dünyanın çeşitli yerlerinde bulunan binlerce mağara resmi eski ressamlara günümüz ressamları arasında doğrudan bir bağlantı işlevi görmektedir.

Sinematografi 1982' de Lumiere kardeşler tarafından icat edildiğinde henüz sanat dalı olarak görülmüyordu. Başlarda filmler oldukça kısa dakikalar hatta saniyeler sürüyordu renksizdi ve sessizdi. Fakat mağara duvarına av resimleri süsleyen atalarımızdan bu yana dünya çok değişmişti. Sinema da gelişen insanlık tarihi gibi gelişti ve sinema bir sanat dalı olarak sayılmaya başlandı. Sinema ve felsefe arasındaki ilişkiye felsefeciler ya da felsefeye aşina olan bazıları filmlerden yararlanırken, filmi sadece diyaloglar, öykü ve olay örgüsünden ibaret olarak görebilmektedir. Oysa bir filmi oluşturan Epstein'in deyimiyle "fotojenik" Faure' nin deyimiyle "sineplastik" ya da sinemada iyice yerleşik hale gelmiş "sinematografik" ögeleri bulunmaktadır. Kadraj, ışık, renk, mizansen, ses, hareket, hız, montaj ve çekim gibi öğeler sinemada anlamın oluşumunun olmazsa olmaz unsurlarıdır. (Sinefilozofi,37) Tüm bu teknik unsurların yanında bir de sinemanın diğer sanat dalları gibi düşündüren ve sorgulatan tarafları da vardır. Jacques Tati'nin "Ben istiyorum ki; film siz sinema salonunu terk ettikten sonra başlasın." sözü de bu bağlamda sinemanın felsefe yapılabilir tarafını kanıtlar.

\section{Blade Runner 2049: Otoriteye Karşı Çıkma Cesareti}

\section{Filmin Analizi}

Blade Runner 2049 (2017) Denis Villeneuve tarafından yönetilmiş bir bilim kurgu filmidir. Film Blade Runner 1982 (Ridley Scott)'nin devam öyküsüdür. Ridley Scott'un yönettiği filmde Tyrell Şirketi insanlığa hizmet etsin diye kopyaları "Replika"ları yaratır. Kopyalar, Tyrell'a "Tanı" diye hitap ederler ve Tanrı'sına başkaldırırlar. Başkaldırma sebebi ölümlü olmalarıdır. Roy, Tyrell'e “Neden bizi ölümlü yaptın?" der ve Tyrell'in gözlerini oyarak onu öldürür. Blade Runner 2049'da ölen Tanrı'nın yerini Wallace Şirketi 
almıştır. 2020 yılının ortalarında ekosistemin çöküşü Sanayici Niander Wallace'in önünü açar. Uzmanlık alanı olan yapay tarımcılık kıtlık yaşanmasına engel olur. Wallace, Tyrel Şirketinden arta kalanları ele geçirir ve itaatkâr yeni kuşak kopyalar yaratır. Hayatta kalan Nexus 8'lerin (Kopyaların) peşlerine düşülür ve kaldırılırlar. Onları avlayanların ismi de halen "Blade Runner" olarak anılmaktadır. Ekosistem çökmüş ve yapay tarımcılık çağının başladığını gösteren tarım alanları ile başlayan film, dünyadan arta kalanları gösterirken içimizi karartan görüntüler sunar. Dünya çöp haline dönmüştür ve hiç umut yoktur. Eski modelleri avlamakla görevli olan LAPD'de polis memuru olan K (Ryan Gosling) yeni kuşak itaatkâr kopyadır. Son kalan eski bir model olan kopyayı kaldırmak için görevdedir. Son kalan Nexsus 8, K'ye "siz hiç mucize görmediniz" der ve K tarafından kaldırılır. K son kalan kopyanın protein çiftliğinde gizli bir kutu bulur. Kutu kurumuş bir ağacın altıdadır. K ortadan kaldırdığı son Nexsus $8^{\prime}$ in protein çiftliğinde bulduğu gizli kutunun içinde bir kadının (Rachael) kemikleri vardır. Laboratuvarda kadının kemikleri üzerinde inceleme yaparlar ve onun doğum sırasında öldüğünü bulurlar. Asıl fark ettikleri ilginç olan şey ise bir kaosa neden olabilecek şeydir. Kadın bir kopyadır ve insanlar gibi doğurmuştur. İnsanlar ve kopyalar arasındaki tür ayrımını ortadan kaldıracak olan ve devrime sebep olacak olan bu bilgiyi ortadan kaldırmaya, üstünü örtmeye kararlıdırlar çünkü insanlara göre tasarlanmış olan bir şeyin ruhu yoktur. Ruhu olmayan bir şey insana ait özelliklere sahip olması dünya düzenini sarsacaktır. İnsanların bu zamana kadar yapmış olduğu kaldırma işlemi bir kıyımla sonuçlanacak hatta insanlar yaptıkları bu kıyım sebebiyle suçlanacaktır. En önemlisi de dünya da düzensizliğe neden olacaktır işte bu nedenle bu bilgi dünyadan saklanmalıdır.

Film hakkındaki en önemli insanlık problemi şudur: "kopyalarneden öldürülüyor?” İnsan kopyaların ruhu olduğu düşüncesine karşı çıkar ve isyan eden kopyaları ortadan kaldırmak ister. Tanrı'da insan bilgelik ağacından yediği için onu ölümlü olmakla cezalandırmadı $\mathrm{m}$ ? Ceza olarak dünyaya gönderdi ve insanlar çoğalıp birbirlerini öldürmeye başladı. İşte insan o kadar tanrılaştı ki kendisi yerine ağır görevlerden kullanılmak amacıyla köleler olan kopyaları yarattı. Kopyalar insana itaat etmeyi ret edince de onları ortadan kaldırmak istedi.

K LAPD'ye döndüğünde ve onu güvenlik testine girerken görürüz. Testte sorular arasında "Sevdiğin birinin elini tutmak nasıl bir şey?", ve K'nin "Bă̆lantılı" cevabı onun gerçekten itaatkâr kopya olduğu düşüncesini seyirciye inandırır. "Bir tarafinın kayıp olduğunu hissediyor musun?" sorusu ak1llara insanlarda olan ama kopyalarda olmayan " ruh" kavramını düşündürür. Filmde insanlar, kopyaların sevme, birisine âşık olma, çocuk sahibi olma ve hissetme gibi insani davranışların olmadığına inanmaktadır. İşte kopyalarda olmayan şey ruhtur. Bu nedenle onlara köle muamelesi yapılır. İnsanlar tarafından dışlanan bir türdür. İnsan yapımı olan bu endüstri ürünü nasıl olabilir de bir ruha sahip olabilir, insanlar gibi sevebilir ve çocuk sahibi olabilir ki... Filmin ahlaksal olarak problemi olan "kopyalar neden öldürülüyor?" sorusuna insan bu nedenle cevap vermektedir. Yani insana göre ruhu olmayan bir şeyin öldürülmesinde ahlaksal açıdan bir sorun yoktur. Kıyım bir bakımdan insana göre meşrulaştırılmıştır.

K'ninkenditürüneyapılanbu haksızlığanetepkivereceğinimerakederiz. Gördüklerine kendisinden beklendiği gibi kayıtsız mı kalacak yoksa, onunda bir ruhu olabileceği arayışına mı girecektir. Kendisinden beklenen emre karşı gelerek karşılaştığı bu mucize karşısında arayışa girer. Bu onun filmin sonunda itaatkâr kopya olmayacağının ilk adımıdır. Filmin yasak elması budur gidilmemesi gereken şeyin üzerine gitmek, kendisinden beklenilen şeye karşı gelip düşünmek yasak elmayı yemenin ilk adımıdır. Bilinmeyen şeyler karşısında bulduklarımız duygularımızı ortaya çıkarır. Bu yeni mucize karşısında düzeni korumaya kararlı insanlar ve cennette daha fazla yer edinmek için kopyaların sürüm güncellemesine doğurma özelliği katmayı isteyen Wallace Şirketi tarafından ikiye ayrılır. Düzeni korumak türler arasındaki ayrımı korumak demektir. Yani insan insan olarak kalmalı ve kopyalar da 
insana itaat etmelidir. Aslında kopyalar insanın daha iyi hale getirilmiş birer kopyalarıdır. İnsanlara göre ağır işlerden çalışmaları nedeniyle daha güçlüdür, yalan konuşmazlar ve görev bilincinde programlanmışlardır. Kendilerinden beklenen şeyi koşulsuz itaat ederek yapar ve sorgulamazlar. Sevmezler, sevilmezler ve doğurulmadan dünyaya gelirlerdir. $\mathrm{Bu}$ iki güç arasındaki çatışmanın arasında $\mathrm{K}$ çocuğun peşine düşmüştür. Yetimhanedeki kayıtları bulmak için yola çıkar burada dünyada arta kalan yıkıntıları görürüz. Yetimhane de 18.yüzyıl İngiltere'sine bir gönderme vardır. Sanayi devriminde kullanılan işçi çocuklar gibi (Oliver Twist, Charles Dickens) bir tablo çıkar karşımıza ama bu çocuklar köle olarak kullanılan kopyalardır. K ona yerleştirilmiş çocukluk anısındaki gibi bir atı yetimhanede bir yere sakladığını hatırlıyordur. Yetimhaneye gittiğinde çocuğun defter kayıtlarını bulmak ister ama kayıtlar silinmiştir. $\mathrm{K}$ anısındaki gibi atı sakladığı yerde bulur ve kendisinin seçilmiş kişi olduğunu sanar. Çocukluk anısının gerçek mi yapay mı olduğunu merak eder ve anıları yapan Dr. Ana Stalline'yi ziyaret eder. Ana kendisine muhafaza ettiği özel bir alanda çalışıyordur çünkü bağışıklık sistemi hastalıklara karşı savunmasızdır. K ile Ana arasında geçen diyalogda şu ilgi çekicidir. "Gerçek anıların varsa gerçek insan tepkilerin olur." $\mathrm{K}$ oraya anısının gerçek mi yapay mı olduğunu sormaya gitmiştir ve Ana ona anısının gerçek olduğunu birisinin bu anıyı yaşadığını söyler. K artık çocuğun kendisi olduğundan emindir, o doğurulmuştur.

K tutuklandığında amirine çocuğu öldürdüğ̈üne dair yalan söyler ve artık görevinden kovulmuştur. K yetimhanede bulduğu ahşap at oyuncağın özelliklerine baktırır ve atın nereden geldiğini bulur. At yüksek radyasyon kirliliğine maruz kalmıştır ve böyle bir yerde kimsenin orada biri olabileceği düşüncesi akıllara gelmez. K orada bir şey bulurum düşüncesi ile oraya gider. Radyasyon nedeni ile hava oldukça kirlidir ve terk edilmişliğin izbeliği vardır. Otelde çocuğun babası Deckard'ı bulur. Bu karşılaşma ilk başta hiç de dostane olmaz. K artık kendisine Joe adını vermiştir. Deckard'a sorular sorar. Çocuğun annesinin adı Rachael'dır. Rachael kopyadır ve Deckard ile aralarındaki ilişkiden çocukları olmuştur. Doğum sırasında Rachael ölmüş, Deckard ise çocuğun izini kaybettirecek şekilde saklamış sonra da ortadan kaybolmuştur. Wallace Şirketi Joe' nin peşine düşer ve onu bulur Deckard'1 kaçırır. Joe'nun peşine düşen Luv'dur, Wallace tarafından tasarlanan meleklerin en iyisidir. Joe uyandığında kendisini bir kamp ateşinin ortasında bulur. Kopyalar kıyamet gününden sonra bulabildikleri yoldaşlarla birlikte gizli bir örgüt kurmuşlardır. Onlar düzen tarafından dışlanan, sisteme isyan eden kopyalardır. Çocuğu bunca zaman saklayan onlardır ve gün geçtikçe sayıları artıyordur. Düzene karşı savaş açmayı planlamaktadırlar. Çocuğu dünyaya tanitarak kopyaların "basit kölelerden daha fazlası" olduğunu tüm dünyaya kanitlayıp kopyaları insanlara karşı ayaklandıracaklardır. Bebek kopyaların umududur. Bu planları yapan Freysa Joe'ya bebeğin kız olduğunu bunca zaman bunu kendisinin sakladığını söyler. Bebeğin kendisi olduğunu düşünen Joe ise bu durum karşısında hayal kırıklığı yaşar. Yine de Deckard'1 kurtarmak için gider. Luv'u bulur ve onu öldürür. Deckard'1 kurtarır ve onu kızı (Ana) tanıştırdığı sırada kendisi de ölür.

Var olduğumun kanıtı nedir? Beş duyumu işleterek algıladı̆̆ım şeyler mi? Ya duyu organlarım beni yanıltıyorsa? Ya muzip birisi ya da bir şeytan beni aldatıyorsa? Filmden örnek verirsek (Blade Runner 2049, 2017) K'nin başına geldiği gibi ruhu olmayan bir itaatkâr kopya mı? Yoksa düşünen ruhu olan bir varlık mı? Descartes'in verdiği yanıt, eğer bu tür soruları soruyorsam, şüphelendiğime, düşündügüme ve dolayısıyla da var olduğuma dair kanıt bulabilirim şeklinde olmuştur. Eğer var olup olmadığıma dair bu tür soruları sorabiliyorsam "varım" demektir. "Düşünüyorum o halde varım." (Sinefilozofi, 93) 


\section{Kaynakça:}

John Berger, Görme Biçimleri, 27 Bask1, 1999, Metis Yayıncılık.

Dante, İlahi Komedya, 1472

Alexander Cabanel, Düşmüş Melek Tablosu, 1898

Eric Grzymkowski, Sanat 101 Leonardo Da Vinci'den Andy Warhol'a Sanat Hakkında Bilmeniz Gereken Herşey, 5 Baskı, 2015, Say Yayınları.

Serdar Öztürk, Sinefilozofi Kurosawa'nın Düşler'inde Sinefilozofik Bir Yolculuk,1 Baskı 2016, Ankara, Heretik Basın Yayın Sanayi ve Ticaret Limited Şirketi. 